\title{
Salmonella serotypes isolated from tortoises and frogs in Istanbul
}

\author{
BY Ö. ANG, Ö. ÖZEK, E. T. ÇETIN AND K. TÖRECI \\ Department of Microbiology, Tropical Diseases and Parasitology, \\ Istanbul Medical Faculty, University, Istanbul
}

(Received 3 July 1972)

\section{SUMMARY}

The incidence of Salmonella in tortoises and frogs captured in Istanbul was studied. From 31 out of 40 tortoises (77.5\%) and from 16 out of 311 frogs $(5 \cdot 1 \%)$ salmonella strains belonging to 18 and 14 serotypes respectively were isolated.

\section{INTRODUCTION}

There are several reports on the isolation of Salmonella serotypes from coldblooded animals. Although many articles concern the salmonella strains in tortoises, snakes and lizards (LeMinor, Fife \& Edwards, 1958; Özek, Çetin, Anğ \& Töreci, 1965; de Hammel \& McInnes, 1971), there are only a few reports on the presence of salmonellas in frogs (Pantaléon \& Rosset, 1964; Desmet-Paix, Lambion, Van Oye \& Veslemans, 1968; Özek et al. 1969). The present paper records the serotypes and incidence of salmonellas in tortoises and frogs captured in the suburbs of Istanbul.

\section{MATERIALS AND METHODS}

The stools obtained every day from each of the $\mathbf{4 0}$ tortoises, which were kept separately in isolated boxes, were cultured.

Liver, spleen, heart, kidney, leg muscles and intestinal contents of each of 311 frogs were examined separately for the presence of salmonella strains. The frogs, under ether narcosis, were fixed on sterile wooden plates. After cleaning the skin with alcohol, the frogs were dissected with sterile tools. The above mentioned parts of the body were removed, cut into small pieces and inoculated into tubes containing Mueller-Kaufmann and selenite $\mathrm{F}$ broths. After $48 \mathrm{hr}$. incubation subcultures were made on Endo and deoxycholate citrate media. The identification of suspected colonies on these media was carried out with the usual bacteriological and serological techniques.

\section{RESULTS}

From 31 out of 40 tortoises (77.5\%) 17 Salmonella serotypes and two Arizona strains were grown. Table 1 shows the distribution of these among the tortoises. Four different serotypes were grown from each of two tortoises, three serotypes (one an Arizona type) from one, and two serotypes (one Arizona) from 17 tortoises.

Eighteen of the 31 tortoises from which different salmonella serotypes were 
Table 1. Salmonella serotypes isolated from tortoises

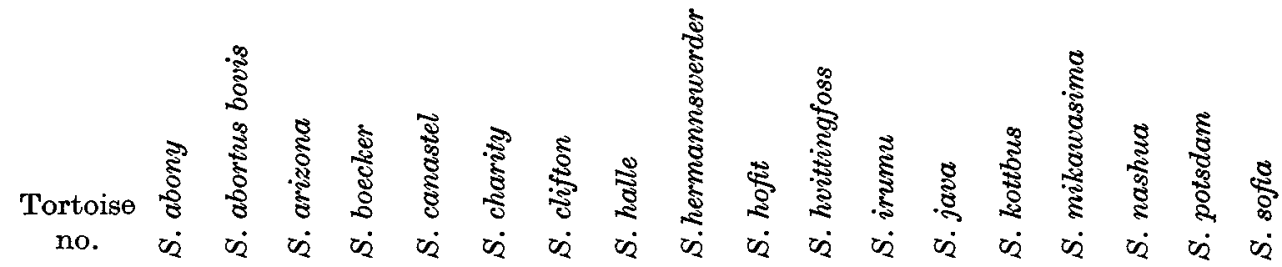

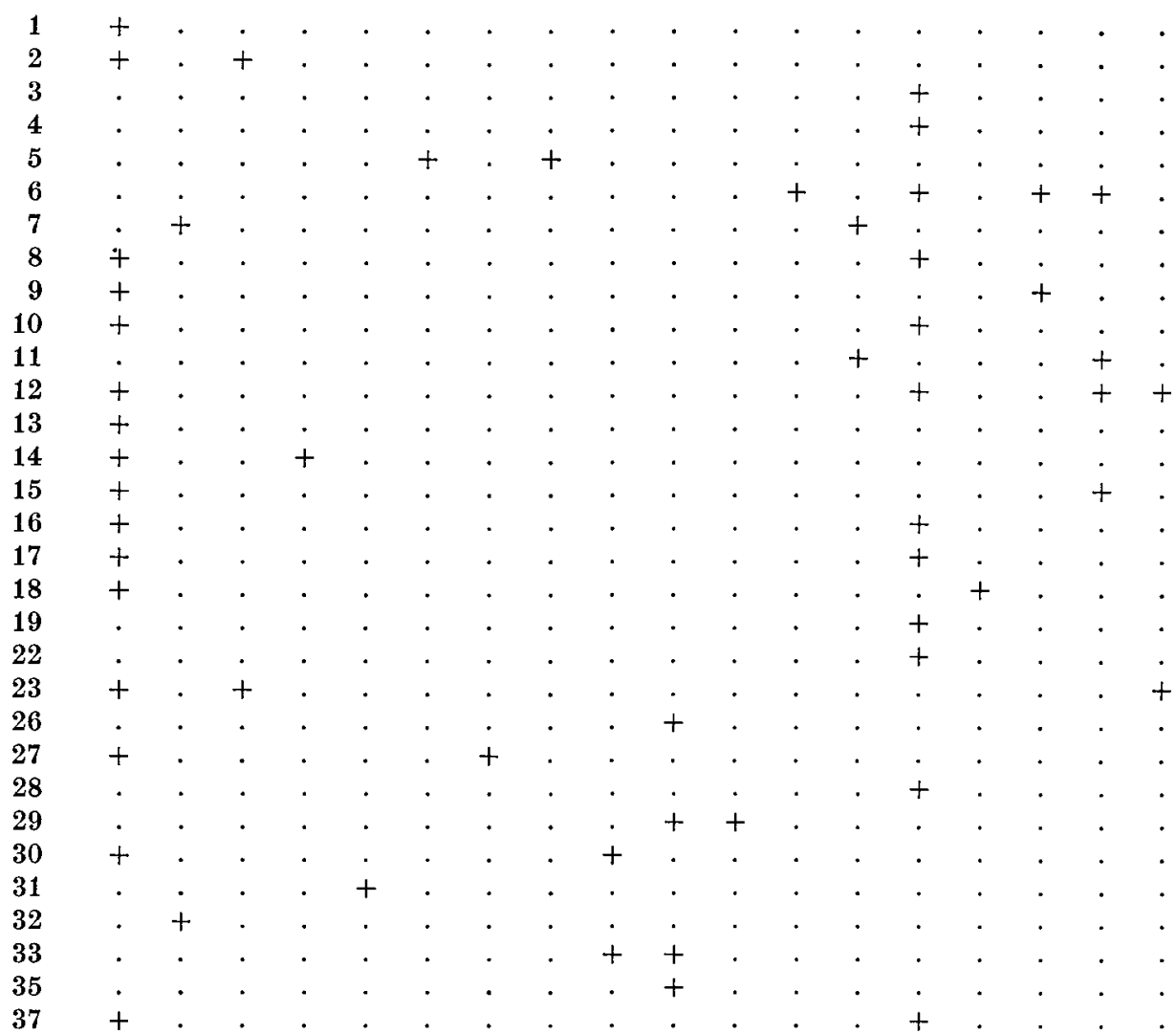

isolated in our investigation were dissected under ether anaesthesia and their bloods were taken. Autopsies were performed and cultures were made from their blood and organs. The media into which their blood and interior organs were added remained sterile.

From 16 out of 311 frogs $(5 \cdot 1 \%) 15$ Salmonella strains belonging to eleven serotypes, and three Arizona serotypes, one of each, were grown. The distribution of these in the organs of individual frogs is shown in Table 2. 
Table 2. Salmonella serotypes isolated from frogs and their sites of isolation

\begin{tabular}{rll} 
Frog no. & \multicolumn{1}{c}{ Site of isolation } & \multicolumn{1}{c}{ Salmonella serotype } \\
17 & Liver & S. bovis-morbificans \\
48 & Liver & S. arizona $\left(47: \mathrm{c}: \mathrm{e}, \mathrm{n}, \mathrm{x}, \mathrm{z}_{15}\right)$ \\
112 & Liver & S. newport \\
113 & Liver and leg muscles & S. newport \\
118 & Liver & S. arizona $\left(61: \mathrm{r}: \mathrm{z}_{53}\right)$ \\
120 & Leg muscles and intestinal & S. hvittingfoss \\
& contents & \\
153 & Intestinal contents & S. abony var. haifa \\
154 & Liver & S. abony, S. kottbus, S. istanbul \\
159 & Liver & S. abony var. haifa \\
164 & Liver & S. arizona $\left(61: \mathrm{i}: \mathrm{z}_{53}\right)$ \\
196 & Liver & S. mikawasima \\
204 & Liver & S. hofit \\
232 & Liver & S. richmond \\
235 & Liver & S. boecker \\
241 & Liver & S. hofit \\
267 & Liver & S. kottbus
\end{tabular}

\section{DISCUSSION}

Salmonella serotypes were first encountered in tortoises in 1946 (Boycott, Taylor \& Douglas, 1953). A number of authors stress the potential importance of tortoises namely pet turtles as carriers of salmonellas. All kinds of tortoises are not salmonella carriers in the same proportion. For example, Vincent, Neel \& LeMinor (1960) found the incidence to be $78 \%$ among the Testuda graeca captured in Maroc, Dimow, Wesselinof \& Rohde (1961) $56 \%$ among tortoises in Bulgaria, and Bövre \& Sandbu (1959) $81.8 \%$ in Norway among the tortoises brought from the Mediterranian countries.

The presence of salmonellas in frogs was established by some reports (Pantaléon \& Rosset, 1964; Desmet-Paix et al. 1968). This finding may be especially important for human health in countries where frog meat is consumed. In Canada, several Salmonella serotypes were isolated from imported and native frogs legs. In France Pantaléon \& Rosset (1964) found 31 out of 164 specimens of imported frog muscles to contain one or two of 13 different serotypes. Of these, S. newport and S. hvittingfoss were also encountered in our study. In the present work, the specimens were taken from each living animal to gain an accurate opinion about the percentage of salmonella organisms in frogs. This also prevented contamination from other sources which might occur in the course of the preparation of frogs' leg muscles as canned food, which were investigated by other authors. Sixteen of 311 frogs $(5 \cdot 1 \%)$ were found to contain salmonella strains. One of the frogs had three serotypes in the liver. In two frogs, two different specimens gave positive cultures for the same serotypes. The presence of salmonella strains only in the liver in thirteen instances suggests that the first organ to be examined is the liver, but the reason for this finding is obscure.

Nearly all of the Salmonella serotypes isolated from tortoises and frogs in this study were encountered in Turkey for the first time. 


\section{REFERENCES}

Bövre, K. \& SANDBU, P. (1959). Salmonella excreting tortoises in Oslo. Acta Pathologica et Microbiologica Scandinavica 46, 339-42.

Boycotr, J. A., TAylor, J. \& Douglas, S. H. (1953). Salmonella in tortoises. Journal of Pathology and Bacteriology 65, 401-11.

DeHAMEL, F. A. \& MCINNES, H. M. (1971). Lizards as vectors of human salmonellosis. Journal of Hygiene 69, 247-53.

Desmet-Paix, L., Lambion, R., Van Oye, E. \& Veslemans, A. (1968). Sur l'importance epidemiologique de la présence de Salmonella dans des coisses de grenouilles surgelees. Revue des Fermentations et des Industries Alimentaries 23, 220-5.

Dimow, L., Wesselinor, W. \& RohDE, R. (1961). Salmonellabefall von Landschildkröten (testudo graeca) in Bulgarien. Zeitschrift für Hygiene und Infektionskrankheiten 148, 135-41,

LeMinor, L., Fift, M. A. \& Edwards, P. R. (1958). Recherches sur les salmonella et arizona hébergées par les vipères de France. Annales de l'Institut Pasteur 95, 326-33.

ÖzEK, Ô., ÇETín, E. T., ANĞ, Ö. \& TöREcti, K. (1965). Kaplumbağalarin salmonella epidemiyolojisindeki yeri. Tip Fakiultesi Mecmuasi (Istanbul) 28, 1-9.

ÖzeK, Ö., Çetín, E. T., ANă, Ö., TöReCi, K. \& SAANII, Z. (1969). Salmonella serotypes isolated from frogs (Rana ridibunda). Zentralblatt für Bakteriologie, Parasitenkunde, Infektionskrankheiten und Hygiene, I. Orig. 210, 557-9.

Pantalíon, J. \& Rosset, R. (1964). Sur la présence de Salmonella dans les grenouilles destinées à la consommation humaine. Annales de L'institut Pasteur de Lille 15, 225-7.

Vincent, J., NeEL, R. \& LeMinoR, L. (1960). Les Salmonella des tortues. Contribution à étude des salmonella du Maroc. Maroc Médical 39, 1076-9. 